\title{
Reforming the Juvenile Justice System
}

\author{
Karen W. Amorose ${ }^{t}$
}

Karen Amorose is a master of public administration candidate studying public organization management. She works in the Natural Resources Conservation Service at the U.S. Department of Agriculture and has established a career in human resources management. Ms.Amorose received her bachelor of arts degree in political science from the University of Maryland at College Park.

Juvenile crime is one of our nation's most serious problems. Headlines such as "Kids Who Kill" routinely capture the front page of today's newspapers and television news programs. The stories are haunting: an eleven-year-old Chicago youth shoots and kills an innocent fourteen-yearold girl with a bullet intended for a rival gang member. ${ }^{1}$ The eleven-year-old boy was killed three days later, allegedly by the rival gang. In Raleigh, North Carolina, a twenty-two-year-old woman is brutally assaulted by her thirteen-year-old neighbor. ${ }^{2}$ The stories are endless.

Juvenile crime is not a new problem, but the dimensions have changed dramatically. When the juvenile justice system was first created more than a century ago, children were committing relatively minor crimes and youth were considered to be more easily rehabilitated than adults. The emphasis of the system was on treatment and rehabilitation. Under the doctrine of parens patriae, a court could act as a guardian of a minor child when problems occurred with the family or in school. ${ }^{3}$ The court was able to take custody of neglected or delinquent children and place them in reform schools to prevent future problems.

At the turn of the twentieth century, the first juvenile courts were established apart from the adult system. The new system had a wide jurisdiction, ranging from serious criminal offenders to neglected children. ${ }^{4}$ The juvenile courts were designed to focus on the "best interests of the child" and have greater flexibility in deciding appropriate treatment. $^{5}$

Beginning with the In re Gault decision in 1967, the Supreme Court mandated for the first time procedural safeguards for juvenile offenders. As a result, any juvenile charged with a serious crime has the right to a notice of charges, a hearing, and assistance of counsel. ${ }^{6}$ Additionally, juveniles must be proven guilty by the criminal standard of "beyond a reasonable doubt." However, in most jurisdictions, juveniles do not have the right to a jury trial.

Today, many citizens believe the juvenile justice system is too lenient. The American public is calling for harsher sentences for juveniles convicted of the most serious crimes. In a 1993 Gallup poll, 73 percent of the respondents said that juveniles who commit violent crimes should be treated the same as adults." The public outcry to curb violent juvenile crime has reached a new urgency.

Grim statistics support public perception that serious juvenile crime is increasing at an alarming rate. From 1982 to 1991, juvenile arrests for violent crimes almost doubled. During this ten-year period, the number of juvenile arrests for murder increased by 93 percent and for aggravated assault by 71 percent." The most dramatic tise in violent juvenile crime began in 1988. From 1987 to 1991, there was a 50 percent increase in juveniles arrested for violent crime."

Youth crime is not only becoming increasingly violent, but crimes are being committed by younger children. In 1990, more than half of the delinquency cases handled by U.S. juvenile courts involved youth age fifteen or younger. Children age twelve and under committed thirty-five murders and five thousand aggravated assaults in 1991."1

Juvenile cases involve teenagers and children charged with murder, rape, armed robbery, and aggravated assault. A system that was designed to handle minor offenses over a century ago is struggling to adequately address the existing juvenile crime problem. Lawmakers and judges have responded by transferring some of the more serious juveniles to adult court. Some states have passed strict gun control laws. Nevertheless, the juvenile crime problem is steadily growing worse. The current system must be reformed. 
According to U.S. Department of Justice statistics, over fifty-three thousand youth are confined to public juvenile correctional facilities nationwide; not surprisingly, overcrowding has become a serious problem. By 1991, juvenile detention and correctional facilities had exceeded design capacity by 47 percent. ${ }^{12}$ Overcrowded correctional facilities result in increased institutional violence and suicidal behavior. ${ }^{13}$ Under such conditions, peer pressure from other delinquent juveniles is pervasive.

Today, many citizens believe the
juvenile justice system is too lenient...
In a 1993 Gallup poll, 73 percent of
the respondents said that juveniles
who commit violent crimes should be
treated the same as adults.

The challenge for policy makers is to design a juvenile justice system that will most effectively address both the small number of dangerous violent offenders and emphasize rehabilitation and prevention for the majority of juvenile delinquents. Accordingly, this article analyzes several alternatives for juvenile justice reform. The various options considered in this article include adult sentencing, mandatory sentencing, boot camps, community-based programs, and a comprehensive prevention strategy. This discussion identifies various alternatives aimed at reducing juvenile crime and recidivism while minimizing costs. Each alternative will be described and analyzed against the criteria identified below.

When looking at juvenile justice reform, a viable policy should reduce crime, be cost-effective, and be acceptable to the public and elected officials. Therefore, the three criteria most critical for this analysis are effectiveness, political viability, and cost.

The effectiveness criterion assesses to what extent a proposed program reduces crime and prevents juvenile offenders from committing additional crime. The short-term and long-term effects of the alternatives will be examined.

Measuring the political viability involves assessing the acceptability of each proposal to various interested groups, e.g., parents, elected officials, and youth advocates. Key stakeholders must be identified who possess the resources, power, and influence to support or reject the various alternatives. By utilizing the criterion of political feasibility, this article investigates which of several alternatives can be implemented with the least political opposition, and what, if any, efforts may be needed to make an alternative more acceptable.

The final criterion concerns the costs of each proposed option, including additional outlays required by the government and taxpayers. These costs may be one-time or recurring and include operating and maintenance expenses. Using this criterion helps identify the alternative that is most cost-effective in reducing crime and re-arrest rates.

In order to effectively examine the proposed approaches to the juvenile crime problem, we must acknowledge the interrelatedness of the criteria which are used in the evaluation. The measures used both complement and contradict one another. For example, an option which is effective in reducing juvenile recidivism rates may be expensive to implement. The cost of the program may also reduce its political feasibility. Understanding how criteria are interconnected is important in determining whether certain modifications can be made to make an option more politically viable.

\section{Sentencing in Adult Courts}

Public sentiment supports the prosecution of juveniles as adults, and many state legislatures have responded by passing laws which automatically prosecute youths as adults for violent crime. In 1993; the Colorado, Utah, and Florida legislatures passed laws permitting specific categories of youth offenders to be prosecuted as adults. ${ }^{14}$ In eleven states, youth at certain ages are excluded from juvenile court. ${ }^{15}$ For example, in New York, youth over age sixteen charged with serious crimes, and minors age thirteen to fifteen accused of certain violent crimes, are prosecuted in adult criminal courts. ${ }^{16}$ As a result of such laws, large numbers of juveniles are already being tried as adults.

Juveniles can also be sent to adult court through judicial waiver. Transfers of juveniles to adult criminal courts increased 68 percent between 1988 and 1992." In fortyeight states, juvenile court judges already have some discretion to waive jurisdiction of juveniles to criminal court at the request of prosecutors. ${ }^{18}$

While sentencing juveniles in adult court is often justified under the rationale of public safety (which diverges from the original intent of the juvenile justice system to protect the best interests of the child), this rationale for adult sentencing does not have a firm grounding in fact. The majority of juveniles sent to adult court are not those charged 
with the most serious violent offenses. Most juveniles transferred to adult courts are chronic property offenders or repeat drug offenders. Between 1984 and 1990, more than half of the juveniles sent to adult prisons were convicted of property offenses and only about 8 percent were convicted of murder or manslaughter. ${ }^{19}$

Although public perception holds that juvenile offenders are treated leniently by juvenile courts, several studies show just the opposite: juveniles are treated more leniently when transferred to adult court. Of course, the definition of "lenient" here is relevant only to the circumstancesjuveniles are treated less harshly in adult courts because juveniles receive shorter sentences than adults appearing in the same court. And since the differing sentences imposed on juveniles and adults may be the result of language in state or federal law, juveniles are treated "leniently" by criminal courts only in comparison to the competition (adults).

Age often becomes a mitigating factor in adult court. Over half of the juveniles transferred to adult court are placed on probation..$^{20}$ In 1992, the California Department of Corrections reports that while youth in the juvenile system spent 60 months in incarceration for homicide, adults spent only 40 months in adult prisons for similar homicide offenses. For robbery, juveniles spent an average of 30 months in youth correctional facilities compared to 25 months for adults.

In addition, laws that transfer jurisdiction of juveniles to adult court may not be effective in reducing crime. One recent study in Idaho found that arrest rates actually increased by 14 percent after the enactment of mandatory waiver laws. ${ }^{21}$ In Florida, the state with the highest number of juveniles sent to adult prisons, the Department of Justice found that juveniles are more likely to return to crime after release from adult prisons. ${ }^{22}$ An evaluation of New York's 1978 juvenile offender law revealed that mandatory waiver of juveniles to adult court had not been effective in reducing juvenile crime. ${ }^{23}$ However, in a study of $16-$ and $17-$ year-olds accused of burglary, researchers in New York and New Jersey found that in the juvenile system, youth were re-arrested less often and remained crime free for longer periods of time. ${ }^{24}$

Another more serious implication is that adult sentencing dismisses the idea that juveniles have potential for rehabilitation. Adult prisons deprive youths of the rehabilitation programs normally received in a juvenile correctional setting. If juveniles are not given an opportunity for rehabilitation, a 13-year-old serving a 20-year sentence in prison will eventually be released with little chance of reassimila tion into society. Further, in adult prisons, juveniles are often subject to abuse, rape, and exploitation by adult inmates. ${ }^{25}$ Juveniles who spend their formative years in adult prisons are likely to become career criminals and eventually re-enter society without rehabilitation, education, or work skills.

Lest we think that sentencing juveniles to adult prisons is the panacea for all the ailments of the juvenile justice system, it should be noted that adult prisons are extremely costly and overcrowded. The Federal Bureau of Prisons reports the average cost of incarcerating one inmate is $\$ 20$ thousand per year. ${ }^{26}$ Further, many adult prisons already exceed capacity, and new prisons would have to be constructed to accommodate an influx of juveniles. The costs of building and operating new prisons to house juveniles $\mathrm{i}$ adult or separate facilities will be prohibitive for most state

The challenge for policy makers is to
design a juvenile justice system that will
most effectively address both the small
number of dangerous violent offenders
and emphasize rehabilitation and
prevention for the majority of juvenile
delinquents.

The costs associated with building new adult facilities are high. Typically, construction costs can range between $\$ 50$ thousand and $\$ 70$ thousand per juvenile and an additiona $\$ 10$ to $\$ 15$ thousand to maintain, guard, and manage eact prisoner. ${ }^{27} \mathrm{~A}$ high security facility costs approximately $\$ 55$ million to build. ${ }^{28}$ Many states are already faced with a lack of funds for the operation of newly-constructed prisons. ${ }^{29}$ Placing juveniles into already overcrowded adult prisons without the money to build new facilities will leac to disaster.

Despite these problems, many states have already passed laws transferring juveniles to adult court, indicating that the political feasibility of this option is fairly high. By passing mandatory waiver laws, legislatures have given voice to the more punitive attitudes held by many members of the general public. Nevertheless, many parents, youth advocates, and juvenile justice officials vehemently oppose adult sentencing because it overlooks the opportunity for rehabilitating youth and puts juveniles at serious risk in adult prisons. 


\section{Longer, Mandatory Sentencing}

Although many segments of society are demanding longer, mandatory sentencing for violent youth offenders, the states appear to be resisting any effort to pass such laws; in fact, thus far, mandatory sentencing laws have only applied to adults who have committed drug or gun-related offenses.

One of the flaws with mandatory sentencing for violent youth offenders is that such tactics would add to the already desperate overcrowding in juvenile facilities. In 1989, the Federal Bureau of Prisons began a nationwide building program to increase prison capacity by fifty thousand beds; unfortunately, this project is not expected to be completed until 1997. In Virginia, the estimated cost of building a 950-bed youth and family services facility in 1995 is $\$ 47.8$ million. ${ }^{30}$

Research shows that programs which do not emphasize rehabilitation have little impact on reducing juvenile crime. ${ }^{31}$ Thus, the extended use of incarceration for youth offenders has questionable public safety benefits. Because 81 percent of youth are arrested for non-violent crimes, longer mandatory sentences will increase the use of incarceration for non-violent offenders.

Instead of ensuring public safety, mandatory sentencing is more likely to turn non-violent juvenile offenders into hardened criminals who will eventually be released into society without sufficient rehabilitation. Two recent studies in the District of Columbia have confirmed that a large number of committed juveniles are not hardened and could benefit from alternative placements. ${ }^{32}$ Mandatory sentencing ignores the fundamental objective of rehabilitating wayward youth and preventing them from committing additional crimes.

Although the general public favors mandatory sentencing, taxpayers may not be willing to pay additional taxes to build and operate new prison facilities for the surge of new inmates resulting from such a policy. In addition, political officials may not be eager to move in this direction because of the high costs associated with longer incarceration and building new facilities. Longer, mandatory sentencing only adds to the problems associated with overcrowding, e.g., higher rates of violence and suicidal behavior. ${ }^{33}$ Youth advocates and parents of at-risk youth favor rehabilitating juveniles rather than incarcerating youth in large correctional facilities for a longer time.

Mandatory sentencing is also extremely costly. Large staterun juvenile correctional programs are already expensive, costing the state and taxpayers between $\$ 35,000$ to $\$ 60,000$ each year for the incarceration of one juvenile. ${ }^{34}$ The annual cost of housing one youth at the Oak Hill Juvenile Correction Center in Laurel, Maryland, is estimated at $\$ 40,000.3^{35}$ Other experts report that the average cost of a juvenile detention center is between $\$ 75,000$ and $\$ 100,000$ per bed. ${ }^{36}$ Additionally, there are enormous costs associated with the "revolving door" of the juvenile coutts. From 60 to 80 percent of all juveniles are rearrested and prosecuted again in juvenile court. ${ }^{37}$

An additional price tag associated with mandatory sentencing is the cost of defending or settling lawsuits filed by inmates challenging the conditions of confinement. For instance, the District of Columbia has paid hundreds of thousands of dollars in fines for failing to address the juvenile overcrowding problem. The District was also under a court order to close one severely overcrowded juvenile facility, address overcrowding in two other facilities, and develop community-based alternatives. Because the District failed to comply with the court order, plaintiffs in this case are now asking that a $\$ 3$ million fine be imposed on the District of Columbia and that daily fines for overcrowding be increased from $\$ 1,000$ per facility to $\$ 1,000$ per juvenile. ${ }^{38}$

In a similar matter, in October 1992, a class action suit was filed on behalf of minors confined in the San Diego Juvenile Hall alleging that overcrowding endangered the physical, emotional, and psychological well-being of children. ${ }^{39}$ The court ordered increases in staffing, mental health services, and rehabilitation for all youth detained in the San Diego Juvenile Hall for longer than fifteen days. Also, each minor suspected of suffering from a mental illness was to be evaluated by a psychiatrist. Additionally, the judge ordered that if the San Diego Probation Department lacked adequate resources, the County Treasurer was required to assure proper medical treatment. ${ }^{40}$ The District of Columbia and San Diego cases demonstrate that class action suits due to the conditions of overcrowded juvenile facilities result in costly litigation and expensive corrective measures.

\section{Youth Boot Camps}

As an alternative to prisons, boot camps provide militarystyle structure, rules, and discipline for convicted young offenders. Most camps have military drills, hard physical training, and work details. A number of boot camp programs offer vocational training, drug and alcohol counseling, and education. The typical duration of a boot camp assignment is 90 to 120 days while some programs may 
last as long as six months.

Juvenile boot camps house youth who receive lesser sanctions, such as prohation. Boot camps typically exclude youth with records of serious violence, armed robbery, and sex offenses. Most programs focus on youth in their middle to late teens, although a few programs take younger offenders. In six of the nine existing juvenile programs, boot camp graduates are assigned to a period of intensive community supervision. ${ }^{91}$

\section{Instead of ensuring public safety, mandatory sentencing is more likely to turn non-violent juvenile offenders into bardened criminals wbo will eventually be released into society without sufficient rebabilitation.}

Many boot camp graduates end up back in prison for minor infractions of the strict, post-camp probation rules or get into further trouble with the law. A 1991 study of Louisiana boot camp graduates found that 37 percent of boot camp attendees were arrested at least once during their first year of freedom compared with 26 percent of all parolees. The arrest rate for boot camp graduates increases significantly the longer camp graduates have been out on the street. ${ }^{42}$ After four years, over half of Georgia's boot camp graduates had returned to prison compared to less than one-third of the comparable offenders on probation. ${ }^{43}$ The most interesting finding of a 1993 New York study is that the re-arrest rate of boot camp graduates compared to individuals who drop out of boot camp is separated by only a few percentage points.

Although some voters have expressed disapproval, public enthusiasm for boot camps is high. Experts comment that boot camps have universal appeal to an angry public because of the "get tough" military drills, strict discipline, and imposing fences surrounding the facility "Elected officials also support this option so as to appear tough on crime and effective at reducing prison overcrowding. In 1992, the governor of Georgia obtained $\$ 14.3$ million from the legislature to expand the state boot camp program. In May 1993 , Florida's governor approved $\$ 4.3$ million for two additional juvenile camps. Moreover, Florida's juvenile boot camp coordinator repots that communities have been eager to donate funds, land, and volunteer services for boot camps.
Overall, boot camps have not resulted in any significant cost savings to states. Of the sixteen states surveyed by the General Accounting Office in 1993, nine states concluded that adult boot camps cost more than prisons." Most state officials involved in this area agree that boot camps (which have larger staffs and better rehabilitative programs than prisons) cost as much or more per day than regular prisons." Additionally, experts argue that boot camps do not reduce prison costs, since many boot camp inmates would not have gone to prison in the first place. ${ }^{19}$

\section{Small, Secure Correctional Facilities and Community-based Aftercare Systems}

In place of large, state-run training schools, small, secure, community-based facilities offer intensive treatment and rehabilitation services for violent offenders and highly-structured, community-based programs for non-violent juveniles. Youth who have committed the more serious, violent offenses are housed in small, secure facilities of $35-40$ beds per unit. Because of the small scale of these programs, staff are able to provide individual treatment, counseling, and supervision. Close proximity to the community allows regular family involvement with juvenile rehabilitation.

Non-violent youth who do not require residential placement are assigned to a wide range of community-based alternatives, such as group homes, home detention, wilderness camps, day treatment, and outreach and tracking programs. These programs provide intensive supervision in the community, as well as counseling and a structured environment. Additionally, all juveniles participate in a variety of treatment and educational community programs. Some examples of community-based programs include the Home Detention Program in Broward County, Florida; the Juvenile Alternative Work Service Programs in Los Angeles and Orange County, California; and the KEY Outreach and Tracking Program in Massachusetts. ${ }^{50}$ Maryland's Youth Advocate Program, another community-based program, provides juveniles subsidized employment with a local employer. Small treatment programs provide the flexibility to make immediate adjustments addressing individual needs without returning to court.

Intensive aftercare services provide close supervision and targeted support as young people re-enter community life. These services facilitate youth-community interaction; encourage participation by family members, peers, schools, and employers; and use graduated sanctions to respond to any technical violations or misconduct. The Ohio RiskBased Aftercare Program has a sanctioning schedule which 
links the seriousness of the infraction to the specific sanction. "Sanctions range from strict curfews to community service to court-ordered house arrest.

Several states already use various forms of communitybased programs. In the early 1970 s, all five of Massachusetts' large state training schools were replaced by a network of small, secure programs for violent offenders and a larger number of highly-structured community-based programs. The small scale of the program permits staff to individualize treatment, rehabilitation, and counseling services. The remaining non-violent youth are divided between non-secure residential programs, day treatment programs, and group homes and all participate in a wide variety of treatment and eductional community programs. ${ }^{{ }^{2}}$

Utah has the most comprehensive copy of the Massachusetts program. In 1980, faced with litigation for civil rights violations, Utah closed its 450-bed state training school. ${ }^{33}$ Contracts with private agencies for services designed to meet the needs of youth were funded with money formerly spent maintaining the state youth training schools. For youth who require secure confinement, Utah maintains two 35-bed, secure, intensive treatment units. ${ }^{5+}$ The remaining youth were placed in group homes, shelter care, and outreach programs.

Maryland, Pennsylvania, and Florida are moving in the same direction as Massachusetts and Utah. Maryland has closed one training school and reduced the population of the remaining juvenile correctional facility. Pennsylvania replaced its training school with a combination of programs administered by state and private organizations.

Smaller community-based programs, with individualized treatment services, have lower recidivism rates, especially when combined with re-entry and aftercare services. In comparison to three other states, the Massachusetts Department of Youth Services (MDYS) facilities had lower recidivism rates than those in states which rely on more traditional large-scale training schools. ${ }^{55}$

Maryland's National Center on Institutions and Alternatives (NCIA) has been actively placing incarcerated juveniles in community-based programs since 1987 . Over a thirteenmonth period, only 31 out of the 497 juveniles released from secure confinement returned to institutions. ${ }^{\text {si }}$ The Massachusetts, Utah, and Maryland examples demonstrate that community-based programs are effective in reducing recidivism rates among juveniles.

The community-based approach is politically appealing because such programs offer an element of punishment as well as rehabilitation. The Massachusetts and Utah reforms received broad bipartisan political support. "Other states, such as Texas, Oklahoma, Oregon, and Florida, have begun to move in the direction of community-based systems. ${ }^{\text {s. }}$

Small, secure treatment facilities and community-based programs are much less costly than large correctional institutions. Estimates are that the MDYS program saves approximately $\$ 11$ million per year. ${ }^{59}$ The average cost per youth is about $\$ 23$ thousand a year compared to the $\$ 35$ to $\$ 45$ thousand per juvenile spent by large corrections programs in many other states." In Utah, the shift to communitybased programs resulted in a decrease of $\$ 250$ thousand from the cost of the old institutional-based system.

\section{Comprehensive Prevention Strategy}

This alternative uses educational and vocational training, life skills development, and family counseling to reduce violent juvenile crime. A number of studies clearly show that chronic juvenile offenders start their criminal careers prior to age twelve and often continue into adulthood. ${ }^{\text {at }}$ To be effective, treatment programs need to begin in early childhood and must be tailored to the unique set of risk and causal factors associated with each youth.

Recent research has identified the major factors affecting delinquency: high-crime neighborhoods, weak family attachments, poor school performance, delinquent peer groups, lack of consistent discipline and behavioral monitoring, and physical or sexual abuse. ${ }^{\text {iz }}$ Prevention programs emphasize healthy social, physical, and mental development of youth and involve all components of the community including schools, families, and community-based organizations. ${ }^{63}$

Prevention programs require communities to identify the primary risk factors faced by children and implement programs aimed at countering these risks. A variety of programs may be needed involving families, schools, peers, and community businesses. Parental support groups, family skills training programs, and family crisis intervention services could be adopted to assist at-risk families. One program funded by the National Institute of Mental Health in Greenville, South Carolina, teaches parents alternative methods of discipline and assists with basic needs, such as jobs and housing. In Austin, Texas, the Children-at-Risk Program is aimed at diverting inner-city kids from involvement with drugs, gangs and crime.

In addition to families, schools play a key role in crime prevention. School programs may include violence preven- 
tion, values development, and vocational training. For instance, a Youth Services Corps could help young people internalize positive individual moral and civic values and teach civilized approaches to resolving conflict using roleplaying. Peer leadership groups could be established for gang prevention, peer counseling, conflict resolution, and teaching individual responsibility. Finally, community organizations and private-sector businesses can offer youth partnerships by providing job training, apprenticeships, and other economic opportunities for juveniles.

Communities are best able to decide what programs and opportunities best fit the needs of young people.

\section{Most social scientists agree that early intervention in the lives of at-risk children is probably the most effective way to tackle violent crime....Most juvenile offenders bave seen violence as a regular part of their environment, and many have been victims themselves.}

Most social scientists agree that early intervention in the lives of at-risk children is probably the most effective way to tackle violent crime. ${ }^{65}$ Research demonstrates that most youth offenders have little understanding of alternatives to violent action and accept the certainty of a dismal and limited future. Most juvenile offenders have seen violence as a regular part of their environment, and many have been victims themselves. Clearly, comprehensive prevention programs that change the risk factors which push youth toward violent behavior will be most effective in the long run.

Although prevention and education at an early age may be the best long-term solution, many Americans are growing impatient with juvenile crime. The American public may not be willing to wait for the benefits of such efforts without more immediate attempts to address the problem. Investment in delinquency prevention may not be a high priority for elected officials facing many other human service demands and shrinking budgets. Further, elected officials may not have the luxury of selecting such a costly option that has no visible and immediate public safety benefits.

Attacking the juvenile crime problem at an early stage is ambitious and costly. Although research exists about a variety of treatment and rehabilitation programs, much more needs to be understood about what works best in preventing serious, violent juvenile crime. Follow-up research and extensive evaluation of performance is needed to determine the results in a variety of settings over time. ${ }^{60}$

\section{Conclusion}

Each of the options has merits and demerits; however, one is clearly superior to other choices. Small, secure correctional facilities and community-based programs clearly stands out as the best policy option.

Community-based programs are already experiencing tremendous success in rehabilitating juveniles. Small, treatment-oriented facilities reduce recidivism among the most serious juvenile offenders up to 70 percent. Individualized treatment and counseling, combined with re-entry and aftercare services, have greatly contributed to the lower rearrest rates. Programs of this nature have had very positive results in a variety of states with different politics, culture, economies, and geography. With an emphasis on family and community involvement, these programs offer opportunities for juveniles that policies which focus on incarceration lack.

Small, community-based programs offer states maximum flexibility in designing appropriate placement based on an individual youth's needs. For non-violent juvenile offenders, alternative treatment is available without incurring the high costs of prisons. Immediate adjustments can be made if the program fails to meet the needs of juveniles.

Community-based programs are overall much less expensive than large, state-run correctional programs.

Community-based programs are also politically appealing because of the intermediate philosophy of combining treatment and punishment. Many elected officials, and particularly the public, need to be better informed of the costeffectiveness of community-based programs. Therefore, a public education strategy would be helpful in making these programs more politically viable.

The comprehensive prevention strategy is the most effective long-term option but is also costly and less politically viable than community-based programs. Prevention programs must begin in early childhood and be aimed at preventing the multiple risk factors affecting youth. A variety of programs will be needed to address diverse needs. Because the focus of a comprehensive prevention program is longrange, an assessment must be conducted several years after the program's implementation. Additional research is needed to accurately measure the results of such a program. 
This option, however, deserves serious consideration as a long-term solution to juvenile crime prevention. Because a comprehensive prevention strategy offers education, vocational training, parenting skills, and family counseling aimed at the risk factors of juvenile crime, this alternative will be the most effective in the long run. According to social scientists, early prevention and treatment programs are needed to reduce the risk factors which push youth toward crime in the first place.

\section{Small, secure correctional facilities and community-based programs are clearly more effective and less costly than large juvenile corrections programs and boot camps.}

Although the public tends to support adult and mandatory sentencing, the cost of implementation is high.

Furthermore, studies clearly show that this approach is ineffective in reducing re-arrest rates. Non-violent youth offenders who could be placed in alternative programs are locked up in expensive prisons. Placing juveniles in prisons for longer periods of time incurs high costs and turns juveniles into career criminals.

Another option which also enjoys a great deal of public support-boot camps-has high re-arrest rates and is as costly as building additional prisons. Furthermore, the longer the period that boot camp graduates are free, the higher the chance of re-arrest. While some boot camps offer treatment and rehabilitation programs, few provide the vocational skills or aftercare services needed for successful transition into community life.

Both of these options ignore the opportunity for rehabilitation and education for the majority of non-violent youth. Instead, the youthful offenders are placed into confinement with much older and more seasoned criminals.
Contrary to popular belief, these "get-tough" policies provide a false sense of security and have questionable public safety benefits. Additionally, such programs ignore the opportunity for rehabilitation and education for the majority of non-violent youth and, instead, turn juveniles into tough criminals. Adult and mandatory sentencing only adds to prison overcrowding at increased costs to the taxpayers. The public ends up paying the high costs of building and operating new facilities to relieve the overcrowding of prisons with non-violent dnug and property offenders.

Small, secure correctional facilities and community-based programs are clearly more effective and less costly than large juvenile corrections programs and boot camps. To make this option more politically viable, the program should be accompanied by a public education strategy which would inform the community of the benefits of such an approach. The strategy would educate people about the low recidivism rate of small, treatment-oriented facilities and the ineffectiveness of the "get-tough" policies. Because of the great concern for public safety, the community may need to be reassured that violent offenders will be locked up in secure facilities and provided intensive counseling and rehabilitation. Elected officials and the public must also be educated about the importance of successfully rehabilitating and educating youth who will eventually reenter society.

Money and resources must follow juveniles out of the institutions and into the community. State legislatures would have to reallocate funds to ensure the success of these programs. States would also need to provide oversight and evaluation to ensure effective and equitable delinquency treatment.

Small, secure correctional facilities and community-based programs will not solve all of the problems associated with juvenile crime. For this reason, serious consideration should also be given to a longer-term prevention strategy. Although more costly, a policy aimed at the risk factors which lead to juvenile crime is needed for success in juvenile crime prevention. $*$

\section{Notes}

II wish to thank my editors, Philip Bransford, Heather Johnston, and Elizabeth Hamill, and Professor Jill Kaste for their encouragement, advice, and invaluable assistance. I would also like to thank Professor Bayard Catron whose assignment inspired this article. Finally, I wish to thank Justin Karlinchak for his constant support and patience.
"Nancy R. Gibbs, "Murder in Miniature," Time Magazine, September 19, $1994,56$.

Richard Iacayo, "When Kids Go Bad," Time Maguzine, September 19, 1994, 60.

Theodore N. Ferdinand, "History Overtakes the Juvenile Justice System," Crime and Delinquency 37 (1991), 207. 
FFerdinand, 209.

5Barry C. Feld, "Juvenile (In) Justice and the Criminal Court Alternative," Crime and Delinquency, (Sage Publications, October 1993), 404.

6Feld, 405.

${ }^{7}$ Feld, 405

${ }^{B} U . S$. Department of Justice, Bureau of Justice Statistics, Sourcebook of Criminal Justice Statistics, 1993, 197.

${ }^{9} \mathrm{U}, \mathrm{S}$, Department of Justice, Office of Juvenile Justice and Delinquency Prevention (OJJDP), Comprebensive Strategy for Serious, Violent, and Chronic Juvenile Offenders, (Washington, D.C.: Office of Juvenile Justice and Delinquency Prevention, 1994), 2.

${ }^{10}$ Michael A. Jones and Barry Krisberg, Ph.D., Images and Reality: Juvenile Crime, Youth Violence and Public Policy, (San Francisco: National Council on Crime and Delinquency, 1994), 21.

"Sarah Glazer, "Juvenile Justice," The Congressional Quarterly Researcher 4 (1994): 177, statistics taken from FBI Uniform Crime Reports.

${ }^{12}$ U.S. Department of Justice, OJJDP, Comprehensive Strategy, 3.

${ }^{13}$ U.S. Department of Justice, Conditions of Confinement: Juvenile Detention and Corrections Facilities, February 1994, 7

${ }^{14}$ Alex Kotlowitz, "Their Crimes Don't Make Them Adults," New York Times Magazine, February (1994), 40.

${ }^{15}$ U.S. Department of Justice, How Juveniles Get to Criminal Court, October 1994, 3 .

${ }^{16}$ National Council on Crime and Delinquency (NCCD), Juvenile Justice Policy Statement, April 1991, 4.

17Jeffrey A. Butts, Ph.D., "Offenders in Juvenile Court, 1992," OJJDP Update on Statistics, derivation of a report prepared for the U.S. Department of Justice, October 1994, 7.

${ }^{18}$ Dean J. Champion and Larry G. Mays, Transferring Juveniles to Criminal Courts: Trends and Implications for Criminal Justice (Westport: Praeger Publishers, 1991), 68.

${ }^{9} \mathrm{U} . S$. Department of Justice, Comprebensive Strategy for Serious, Violent and Cbronic Juvenile Offenders, 5.

${ }^{20}$ Champion and Mays, 78.

${ }^{21} J o n e s$ and Krisberg, 34.

${ }^{22}$ Glazer, 176.

${ }^{23}$ S. I. Singer and McDowall, "Criminalizing Delinquency: The Deterrent Effects of New York Juvenile Offender Law," Law and
Society Review 22 (1988), 521.

${ }^{24}$ Jones and Krisberg, 26.

${ }^{25}$ Champion and Mays, 94.

${ }^{26}$ U.S. Congress, House, Facts on Federal Bureau of Prisons, December 1992, Committee on the Judiciary, Appendix 6 of Report No. 103-465, p. 434.

${ }^{27}$ Alfred Blumstein, Prison Crowding, A Crime File Study Guide prepared for the National Institute of Justice, U.S. Department of Justice, 2.

${ }^{28}$ Peter Baker and P. Donald, "Virginia Prisons Swamped by Inmate Rise," Washington Post, 20 February 1995, D7.

${ }^{20}$ House, Committee on the Judiciary, Future Prison Population: Present and Future Trends, 12 May 1993, 2.

${ }^{3}$ Baker and Donald, D7.

${ }^{31}$ Jones and Krisberg, 35.

${ }^{32}$ Brown and Bowden, Juvenile Justice, citing studies of the Robert F. Kennedy Memorial \& National Council on Crime and Delinquency, "At the Crossroads: Juvenile Corrections in the District of Columbia," (March 1993), 272.

${ }^{33}$ U.S. Department of Justice, OJJDP, Comprehensive Strategy for Serious, Violent and Chronic Juvenile Offenders, 37.

${ }^{34}$ Jones and Krisberg, 43.

${ }^{35}$ Brown and Bowden, Juvenile Justice, 270.

${ }^{36}$ Michael J. Dale and Carl Sanniti, "Litigation as an Instrument for Change in Juvenile Detention: A Case Study," Crime \& Delinquency, January 1993, 62.

${ }^{37}$ National Council on Crime and Delinquency.(NCCD), Unlocking Juvenile Corrections: Evaluating the Massacbusetts Department of Youth Services, 1991: 19.

${ }^{38}$ Brown and Bowden, Juvenile, Justice, 273.

${ }^{30}$ Keith G., et al, v. Brian Bilbray, Superior Court of California, (County of San Diego, October 21, 1992), 1.

${ }^{10}$ Keith G., et al, v. Brian Bilbray, 81.

${ }^{41}$ Roberta C. Cronin, Boot Camps for Adult and Juvenile Offenders, A Research Report for the National Institute of Justice, U.S. Department of Justice, (1994), 35.

12Peter Katel, "The Bust in Boot Camps," Newsweek, February 21, $1994,26$.

${ }^{43}$ Glazer, 181.

MCronin, 45. 
${ }^{45}$ Cronin, 6.

${ }^{46}$ Glazer, 180.

${ }^{47}$ Cronin, 42.

${ }^{48}$ Cronin, 31.

${ }^{49}$ Glazer, 181.

${ }^{50}$ U.S. Department of Justice, Comprebensive Strategy for Serious, Violent, and Cbronic Juvenile Offenders, 7.

"U.S. Department of Justice, Office of Juvenile Justice and Delinquency, Intensive Aftercare for High Risk Juveniles: Policies and Procedures, 20.

${ }^{32} \mathrm{NCCD}$, Unlocking Juvenile Corrections: Evaluating the Massacbusetts Department of Youtb Services, 2.

5.Dan Macallair, "Reaffirming Rehabilitation in Juvenile Justice," Youth E Society, 25 (September 1993), 114.

${ }^{54}$ Macallair; 114.

${ }^{5} \mathrm{NCCD}$, Unlocking Juvenile Corrections: Evaluating the Massacbusetts Department of Youth Services, 17. The National Council on Crime and Delinquency (NCCD) conducted a ten-year follow-up study and found that the 12-month recidivism rates for MDYS youth showed a significant decline in the incidence and severity of crime. The study found that the Massachusetts re-arrest rate of 51 percent was considerably lower than the 66 percent recidivism rate of youth released from the large training schools. The same study also revealed that youth who spent five months in the Massachusetts program had a 20 percent lower re-arrest rate than youth who spent 14 months in a Califormia institution.

56Vincent Schiraldi, "Hawaii's Juvenile Justice System: A Model for Reform," Federal Probation, 54 (1990), 59.

${ }^{5}$ NCCD, Unlocking Juvenile Corrections: Evaluating the Massacbusetts Department of Youth Services, 7 and 23.

5月Ibid., 24.

"U.S. Department of Justice, Comprebensive Strategy for Serious, Violent and Cbronic Juvenile Offenders, 7.

${ }^{60}$ Theodore N. Ferdinand, "History Overtakes the Juvenile Justice System," Crime and Delinquency, 37 (1991), 216.

${ }^{6}$ U.S. Department of Justice, Comprebensive Strategy for Serious, Volent and Cbronic Juvenile Offenders, 35.

${ }^{62}$ Ibid., 6.

${ }^{6}$ U.S. Department of Justice, Comprebensive Strategy for Serious, Violent and Cbronic Juvenile Offenders, 13.

${ }^{64}$ Michael B. Greene, "Chronic Exposure to Violence and Poverty: Interventions That Work for Youth, Crime and Delinquency," 39 (1993), 115.

${ }^{65}$ Terence P. Thornberry et al., "Testing Interactional Theory: An Examination of Reciprocal Causal Relationships Among Family, School, and Delinquency," The Joumal of Criminal Law \& Delinquency, 82 (1991), 32.

${ }^{6}$ U.S. Department of Justice, Comprehensive Strategy for Serious, Violent and Chronic Juvenile Offenders, 24.

\section{Bibliography}

Baker, Peter and Donald P, "Virginia Prisons Swamped by Inmate Rise." Wasbington Post, 20 February 1995.

Bernard, Thomas J. The Cycle of Juvenile Justice. New York: Oxford University Press, 1992.

Blumstein, Alfred. Prison Crowding. National Institute of Justice, U.S. Department of Justice.

Brown, Elizabeth M., Esq. and Bowden, Anne R, Esq., Juvenile Justice, (1994).

Butts, Jeffrey A. Offenders in Juvenile Count, 1992. OJJDP Update on Statistics, Office of Juvenile Justice and Delinquency Prevention, U.S. Department of Justice. (October 1994).

Champion, Dean J. and Larry G. Mays. Transferring,Juveniles to Criminal Courts: Trends and Implications for Criminal Justice. Westport: Praeger Publishers, 1991.
Cronin, Roberta C. Boot Camps for Adult and Juvenile Offenders; National Institute of Justice, U.S. Department of Justice, (October 1994).

Crowe, Thomas. Habitual Juvenile Offenders: Guidelines for Citizen Action and Public Responses, Office of Juvenile Justice and Delinquency Prevention, October 1991.

Dale, Michael J. and Carl Sanniti. "Litigation as an Instrument for Change in Juvenile Detention: A Case Study." Crime and Delinquency, 39 (1993): 49-67.

Dawson, Robert $\mathrm{O}$. "The Future of Juvenile Justice: Is It Time to Abolish The System?" The Journal of Criminal Law and Criminology 81 (1990): 136-155.

Eisenman, Russell. "Society Confronts the Hard-Core Youthful Offender." USA Today 122 (January 1994).

Feld, Barry C. "Juvenile (In) Justice and the Criminal Court Alternative," Grime and Delinquency, (Sage Publications, October 1993). 
Ferdinand, Theodore N. "History Overtakes the Juvenile Justice System." Crime and Delinquency 37 (1991): 204-224.

Gibbs, Nancy R. "Murder in Miniature." Time Magazine 56 (September 1994).

Glazer, Sarah. The Congressional Quarterly Researcher. "Juvenile Justice," vol. 4, 1994): 169-192.

Greene, Michael B. "Chronic Exposure to Violence and Poverty: Interventions That Work for Youth," Crime and Delinquency. 39 (1993), 106-121.

Hawk, Kathleen, Director, Federal Bureau of Prisons, Testimony at the 1993 Prison Population Hearing, U.S. House of Representatives, May 12-13, 1993.

Hirschi, Travis and Gottfredson. "Rethinking the Juvenile Justice System." Crime and Delinquency 39 (1993): 262-271.

Horowitz, Craig, "Disorder: How the Juvenile Justice System is Letting Kids Get Away With Murder." New York, 10 January 1994, 24-27.

Jensen, Eric L. and Linda K. Metsger. "A Test of the Deterrent Effect of Legislative Waiver on Violent Juvenile Crime." Crime and Delinquency 40 (1994): 94-104.

Jones, Michael A. and Barry Krisberg, Ph.D. Images and Reality: Juvenile Crime, Youtb Violence and Public Policy. San Francisco: National Council on Crime and Delinquency, 1994.

Katel, Peter. "The Bust in Boot Camps." Newsweek, 21 February 1994.

Keith G., et al., v. Brian Bilbray, Superior Court of California, (County of San Diego, October 21, 1992).

Kotlowitz, Alex. "Their Crimes Don't Make Them Adults." New York Times Magazine, 13 February 1994.

Lacayo, Richard. "When Kids Go Bad." Time, 19 September 1994.

Macallair, Dan. "Reaffirming Rehabilitation in Juvenile Justice." Youth \& Society, 25 (1993): 104-123.

McShane, Marilyn D. and Frank P. Williams III. "The Prison Adjustment of Juvenile Offenders." Crime and Delinquency 35 (1989): 254-269.

National Council on Crime and Delinquency. Juvenile Justice Policy Statement. San Francisco: National Council on Crime and Delinquency, 1991.

National Council on Crime and Delinquency. Unlocking Juwenile Corrections: Evaluating the Massacbusetts Department of Youth Services. San Francisco: National Council on Crime and Delinquency, 1991.
S.I. Singer and McDowall. "Criminalizing Delinquency: The Deterrent Effects of the New York Juvenile Offender La Law and Society Review, 22 (1988): 521-535.

Schiraldi, Vincent, "Hawaii's Juvenile Justice System: A Mor Reform." Federal Probation 54 (1990): 58-62.

Thornberry, Terence P., et al., "Testing Interactional Theory Examination of Reciprocal Causal Relationships Among Family, School, and Delinquency." The Journal of Crimi Law E Delinquency. 82 (1991), 3-33.

U.S. Congress, House. Committee on the Judiciary. Federai Population: Present and Future Trends, 103rd Congress. sess., 12 May and 29 July 1993 Hearings, 1-120.

U.S. Congress, House. Committee of the Judiciary, Future 1 Population: Present and Future Trends. 12 May $1993 \mathrm{Ht}$

U.S. Congress, House. Facts on Federal Bureau of Prisons, December 1992, Committee on the Judiciary, Appendix Report No. 103-465.

U.S. Department of Justice. Bureau of Justice Statistics. Sourcebook of Criminal Justice Statistics, Washington, D. 1993.

U.S. Department of Justice. Office of Juvenile Justice and Delinquency Prevention. Comprebensive Strategy for Ser Violent and Chronic Juvenile Offenders. Washington, D. 1994.

U.S. Department of Justice. Office of Juvenile Justice and Delinquency Prevention, Conditions of Confinement: Ju Detention and Corrections Facilities, Washington, D.C.,

U.S. Department of Justice. Office of Juvenile Justice and Delinquency Prevention. How Juveniles Get to Criminal Washington, D.C., 1994.

U.S. Department of Justice. Office of Juvenile Justice and Delinquency Prevention. Intensive Aftercare for High Ris Juveniles: Policies and Procedures, Washington, D.C., 19

U.S. Department of Justice. Office of Juvenile Justice and Delinquency Prevention, Juvenile Justice: Drugs, Delinq and Other Data. Washington, D.C., 1994.

U.S. Department of Justice. Office of Juvenile Justice and Delinquency Prevention. Office of Juvenile Justice and Delinquency Prevention Update on Statistics. Washingtor. 1993.

Yoshikawa, Hirokazu. "Prevention as Cumulative Protection Effects of Early Family Support and Education on Chron Delinquency and Its Risks, Psycbological Bulletin. 115 (1) 28- 48. 